\title{
Laboratory diagnosis of persistent human chlamydial infection
}

\author{
Mirja Puolakkainen ${ }^{1,2 *}$ \\ ${ }^{1}$ Department of Virology, Haartman Institute, University of Helsinki, Helsinki, Finland \\ 2 HUSLAB, Department of Virology and Immunology, Helsinki University Central Hospital, Helsinki, Finland
}

\section{Edited by:}

Nicole Borel, University of Zurich,

Switzerland

Reviewed by:

Jan Rupp, University of Lübeck, Germany

James T. Summersgill, University of Louisville, USA

${ }^{*}$ Correspondence:

Mirja Puolakkainen, Department of Virology, University of Helsinki,

Haartmaninkatu 3, 000290 Helsinki,

Finland

e-mail:mirja.puolakkainen@

helsinki.fi
Diagnostic assays for persistent chlamydial infection are much needed to conduct high-quality, large-scale studies investigating the persistent state in vivo, its disease associations and the response to therapy. Yet in most studies the distinction between acute and persistent infection is based on the interpretation of the data obtained by the assays developed to diagnose acute infections or on complex assays available for research only and/or difficult to establish for clinical use. Novel biomarkers for detection of persistent chlamydial infection are urgently needed. Chlamydial whole genome proteome arrays are now available and they can identify chlamydial antigens that are differentially expressed between acute infection and persistent infection. Utilizing these data will lead to the development of novel diagnostic assays. Carefully selected specimens from well-studied patient populations are clearly needed in the process of translating the proteomic data into assays useful for clinical practice. Before such antigens are identified and validated assays become available, we face a challenge of deciding whether the persistent infection truly induced appearance of the proposed marker or do we just base our diagnosis of persistent infection on the presence of the suggested markers. Consequently, we must bear this in mind when interpreting the available data.

Keywords: diagnosis, persistent infection, Chlamydia pneumoniae, Chlamydia trachomatis, proteomics

\section{BACKGROUND}

The clinical spectrum of human chlamydial infections includes clinically unapparent infections, acute symptomatic infections as well as persistent infections (defined as the presence of viable but non-cultivable chlamydiae). Persistent Chlamydia psittaci infection in cultured cells was described over 30 years ago (Moulder et al., 1980). Similar continuous infection models in cell lines without external induction have later been established for Chlamydia trachomatis (Lee and Moulder, 1981) and Chlamydia pneumoniae (Kutlin et al., 1999). In cultured cells, persistent infection can also be induced by external factors, including amino acid starvation, interferon- $\gamma$-induced tryptophan deprivation, iron chelation, tobacco smoke and viral co-infection as well as by exposure to antimicrobial agents (for review, see Beatty et al., 1994; Hogan et al., 2003). Furthermore, chlamydial infection in monocyte/macrophage cultures has the appearance of a persistent infection (Mannonen et al., 2004, 2011). The presence of large, pleomorphic reticulate bodies, named aberrant bodies, inhibition of binary fission and inability of the aberrant bodies to transform into infectious elementary bodies, characterize in vitro persistence. Transcriptomic and proteomic analyses have confirmed that there is continued genome replication and messenger RNA synthesis in the aberrant bodies, but altered cell division (Nicholson et al., 2003; Mäurer et al., 2007).

Although the persistence of C. trachomatis and C. pneumoniae in vitro is rather well studied, much less is known, if the features typical of in vitro persistent infection also characterize persistent experimental or human chlamydial infection.
Recently, aberrant bodies were shown to develop in uterine horns of mice infected with C. muridarum and treated with amoxicillin (Phillips Campbell et al., 2012). Amoxicillin treatment also reduced vaginal shedding of infectious EB while accumulation of the chlamydial pre-16s rRNA was unaffected (Phillips Campbell et al., 2012). This indicates that chlamydial persistent infection can occur in vivo. As the bacteria become dormant and persistent, they are suggested to evade host protective immune responses, although the immune system can be still be stimulated at low-level which may contribute to the development of immune-mediated pathology (Beatty et al., 1994; Phillips Campbell et al., 2012). Follow-up studies on human ocular and recurrent genital C. trachomatis infections have shown features common to persistent state, such as the frequent detection of chlamydial nucleic acid while the organisms can infrequently be cultured (Hudson et al., 1992; Dean et al., 2000). Clinical data also suggests that $C$. pneumoniae may persist for months after the initial infection (Grayston, 1992), and persistent lung infections despite of antimicrobial therapy have been reported (Falck et al., 1996; Miyashita et al., 2002). C. trachomatis DNA has been demonstrated by in situ hybridization in the fallopian tube tissue from infertile women (Campbell et al., 1993; Barlow et al., 2001). Significantly elevated IgA antibody levels considered suggestive of persistent infection were found among the currently or formerly smoking men compared to their non-smoking co-twins (von Hertzen et al., 1998). Moreover, electron micrographs have demonstrated different stages of $C$. pneumoniae in atherosclerotic plaques (Spagnoli et al., 2007; Bobryshev et al., 2008), and 
antigens whose expression is up regulated during the persistent state of $C$. pneumoniae have been detected in human atheromas (Borel et al., 2012).

In vitro, chlamydial persistence has also been characterized at molecular level. Although the phenotype of persistent infections is rather similar irrespective of the inducer, the transcriptional studies on persistent chlamydial infection have failed to reveal a profile common for different models (Hogan et al., 2003; Goellner et al., 2006; Klos et al., 2009). This might reflect variation in the experimental systems but it could also indicate variability of the mechanisms acting in the different models of persistent infection. Based on the relative chlamydial rRNA transcript levels in persistently infected monocytes and actively growing epithelial cells, the metabolic rate of $C$. trachomatis in monocytes is lower than in the cells where $C$. trachomatis grows productively (Gérard et al., 2002). When chlamydial transcription and translation were analyzed upon IFN- $\gamma$ exposure in the epithelial cells, the global chlamydial transcription was shown to be up regulated but the protein synthesis was reduced suggesting uncoupling of transcription and translation (Ouellette et al., 2006). Although this phenomenon can represent a successful survival strategy for Chlamydiae, it might also mean less potential chlamydia-derived biomarkers available for detection of the persistent stage. Nevertheless, quantitative proteomic profiling of the persistent and the acute chlamydial infection to identify differentially expressed proteins represents a possibility for providing diagnostic targets for the persistent infection. The proteins associated with persistent infection could be useful as biomarkers for the diagnosis, as therapeutic targets, and ultimately as responseto-therapy markers. However, the initial studies in this area also failed to reveal a common profile between different models and different chlamydial species (Mukhopadhyay et al., 2006). Upon exposure to IFN- $\gamma$, the presence of aberrant $C$. trachomatis forms was associated with down-regulation of the outer membrane proteins (OmpA, OmpB) in cell culture, while the expression of chlamydial GroEL was unaltered (Beatty et al., 1993). Attempts to characterize the protein composition of $C$. pneumoniae during persistent stage have shown a marked up-regulation of OmpA and GroEL upon IFN- $\gamma$ exposure, whereas no significant decrease in bacterial protein expression was observed (Molestina et al., 2002). On the other hand, upon iron limitation unchanged levels of C. pneumoniae OmpA and GroEL were observed, while altogether twenty differentially regulated chlamydial proteins were observed (Wehrl et al., 2004). Many of these proteins remained unidentified.

A serum-based assay would be most desirable for the diagnosis of persistent infection. Serum samples are relatively easily obtained whereas tissue samples from the site of persistent infection often require invasive sampling and are thus not readily available. The recent studies on serology during persistent infection suggest that the antibody response could indeed reflect altered protein of chlamydial expression in vivo but this needs further studies (see below). Despite of all the recent discoveries, the development of diagnostic tests for persistent infections remains challenging.

In this minireview, diagnostic options of human persistent chlamydial infection will be discussed (see also Table $\mathbf{1}$ ).

\section{CULTURE}

By definition, the detection of persistent chlamydial infection (defined as the presence of viable but non-cultivable chlamydiae) by culture is not possible. Culture has, however, been successfully used in the early studies on persistency. During experimental mouse infection, Chlamydiae are able to remain in tissues after cessation of shedding and the infection can be reactivated by cortisone treatment (Yang et al., 1983; Malinverni et al., 1995; Laitinen et al., 1996; Cotter et al., 1997). In these studies, mice were infected and the infection was followed by culture. After the clearance of a culture-positive infection, cortisone was administered. This obviously activated persistent Chlamydiae, as infectious bacteria could again be recovered, at least in a proportion of mice.

Although the persistent state is still rather poorly defined in vivo, this observation is of potential significance in human persistent infection: Corticosteroids are included e.g., in the treatment of patients with exacerbations of asthma and chronic obstructive bronchitis, conditions associated with persistent C. pneumoniae infection (Hahn et al., 1991), and the steroid therapy could reactive infection. If this takes place in vivo, it might aggravate infection, and enhance transmission but on the other hand, it might make the bacteria more sensitive to action of antibiotics. There is, however, little, if any clinical data to support this. Partly this could be due to issues related to proper sample collection, as the persistent chlamydial forms can localize in tissues, and not necessarily in the mucosal surface available for swabbing (Cappuccio et al., 1994). Recently, biologic response modifiers have been introduced to the treatment of inflammatory diseases. Whether these new therapies could also reactivate persistent chlamydial infection, remains to be studied.

\section{ANTIGEN DETECTION}

To circumvent limitations of the culture, immunological antigen detection methods, such as enzyme immunoassay and direct immunofluorescence staining were developed for diagnosis of chlamydial infections. Theoretically, detection of a chlamydial antigen in clinical specimens could serve as a diagnostic test for persistent infection. However, the general notion is that the detection of chlamydial EB in mucosal smears indicates presence of a current C. trachomatis (Havlichek et al., 1990) or C. pneumoniae (Grayston et al., 1986) infection. It would obviously require more invasive sampling than swabbing of the mucosa to demonstrate the hallmarks of persistent infection, the aberrant bodies, at the site of infection. Moreover, the amount of aberrant bodies in the specimen is likely to be very small and reagents to visualize them are not readily available.

For research purposes, the detection of chlamydial antigen(s) by immunocytochemistry (ICC) in tissues has proven useful and ICC has assisted studies on clinical features of persistent infections, including post infectious tubal infertility (Patton et al., 1994) and atherosclerosis (Kuo and Campbell, 2000). Instead, detection of a soluble circulating chlamydial antigen could represent a practical tool in diagnosis. The quantification of chlamydial lipopolysaccharide (cLPS) in human sera by enzyme immunoassay represents a potential marker for persistent infection (Tiirola 
Table 1 | Potential biomarkers of persistent human chlamydial infection.

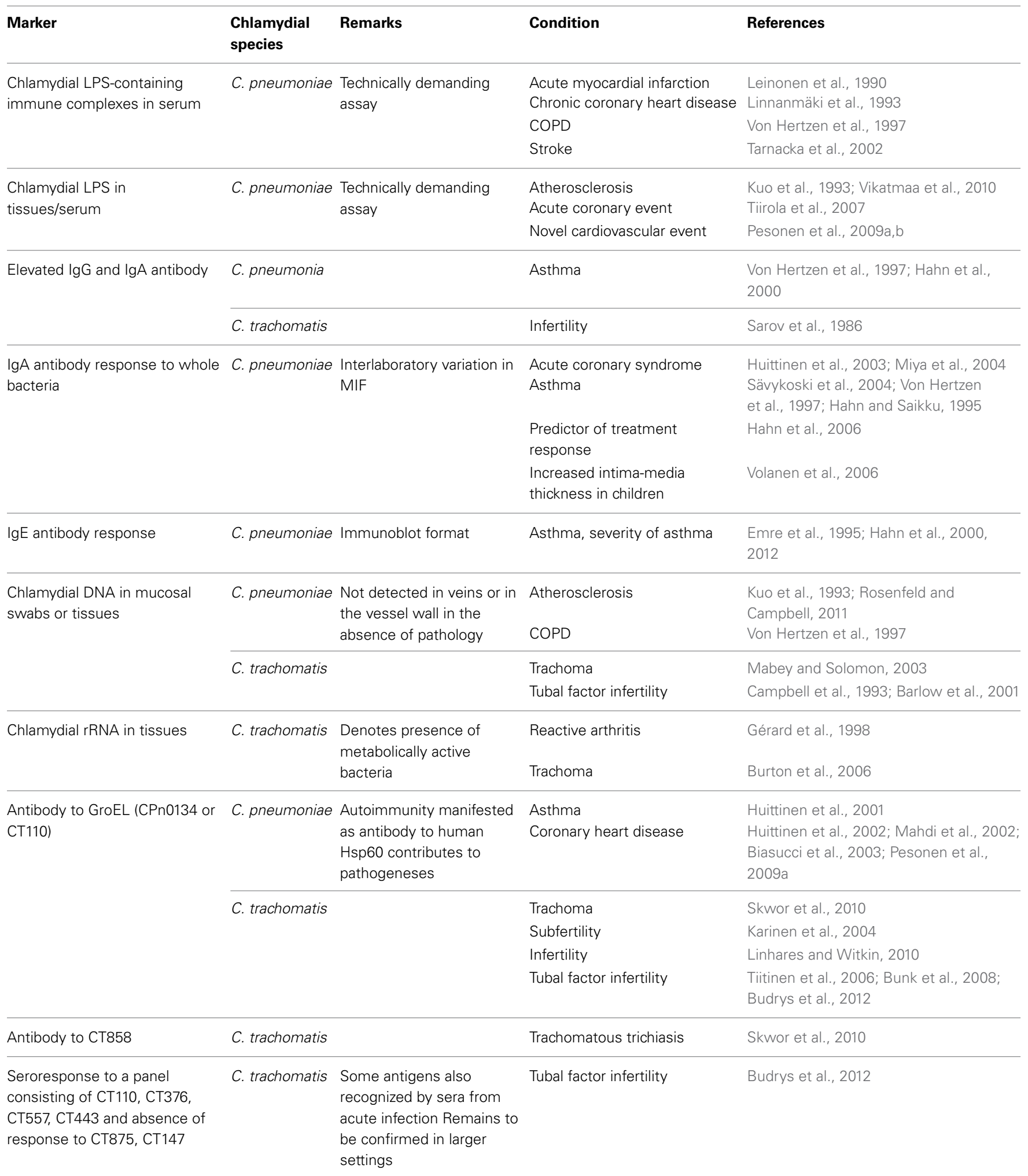

Seroresponse to a panel consisting of antigens CPn0695, CPn0134, CPn0626CPn0702, CPn 449/450, CPn 0854,CPn 0963, CPn1016
C. pneumoniae Remains to be confirmed in larger settings
Presence of $C$. pneumoniae DNA in the coronary artery or in the PBMC
Bunk et al., 2008 
et al., 2006). Chlamydial LPS was detected in serum during acute coronary events and its presence correlated with the C-reactive protein levels (Tiirola et al., 2007). Moreover, the circulating cLPS was associated with a new cardiovascular event during the follow-up period (Pesonen et al., 2009b). Also, circulating chlamydial LPS-containing immune complexes have been suggested to be important in the pathogenesis and serve as markers of persistent infection (Leinonen et al., 1990; Linnanmäki et al., 1993), but the assay is technically rather demanding and it has only been used in research.

\section{NUCLEIC ACID AMPLIFICATION}

Nucleic acid amplification test kits (NAATs) have revolutionized the diagnosis of acute $C$. trachomatis infections offering high sensitivity and specificity. The NAATs, including polymerase chain reaction (PCR), are also well suitable for the detection of persistent chlamydial infection, when lower quantities of Chlamydiae are produced challenging the sensitivity of the detection method. Indeed, the use of amplification technologies and culture has given us clues that persistent, non-cultivable chlamydial infections do occur in vivo. Trachoma in children can often be diagnosed by culture, whereas the agent can no longer been cultured in the blinding stage (Grayston and Wang, 1975). Similarly, C. trachomatis can be cultured in acute lower genital tract infections, while culture rarely succeeds in upper genital infections, including tubal factor infertility, although C. trachomatis DNA can be amplified by PCR (Brunham et al., 1985). The mere demonstration of bacterial DNA does not, however, indicate viability, but could be related to the higher sensitivity of the PCR method per se. Identification of chlamydial rRNA primary transcripts indicates that the bacteria are metabolically active (Gérard et al., 1997). Indeed, in the synovial samples from patients with reactive arthritis primary rRNA transcripts and mRNA from chlamydial genes were present (Gérard et al., 1998).

PCR with C. pneumoniae-specific primers has played an important role in confirming the presence of DNA from these bacteria in atheromas and circulating blood cells. In combination with serology and ICC, the PCR has been a valuable tool in the studies confirming the link between atherosclerosis and infections, especially with persistent C. pneumoniae infection (Campbell and Kuo, 2004; Rosenfeld and Campbell, 2011). Current data supports that this condition represents a persistent infection: Ex vivo culture of C. pneumoniae from atherosclerosis is rare, while PCR can frequently detect chlamydial DNA in diseased tissues (Campbell and Kuo, 2004). Studies in mice show that the presence of $C$. pneumoniae DNA in tissues is an indicator of prior infection, and when the bacteria are not cultivable it is suggestive of persistence, as DNA in the non-viable bacteria degrades fast in vivo (Moazed et al., 1998).

\section{SEROLOGY}

Serology has been a valuable tool in epidemiological studies, in studies describing clinical spectrum of chlamydial infections, including persistent infection, and in research. Serology is also commonly used to diagnose acute C. pneumoniae infections in clinical practice while its value in the laboratory diagnosis of acute C. trachomatis infections is slim. It may, however, prove helpful when studying complications of the acute phase (e.g., reactive arthritis) and manifestations of persistent infections (e.g., tubal factor infertility). Microimmunofluorescence (MIF) test using fixed purified whole bacteria as antigen has been considered a golden standard of chlamydial serology, but automatable enzyme immunoassays (EIA) have taken root in clinical laboratories, partly because the MIF can suffer from subjectivity in interpretation and interlaboratory variation (Peeling et al., 2000). The MIF and most EIAs detect antibody response against proteins on the surface of Chlamydiae, and established guidelines on the diagnostic criteria for acute C. pneumoniae infections are available: IgM appears in the first infection in 3 weeks, IgG in 6-8 weeks, and if adequately timed paired sera are available, $a \geq 4$-fold IgG titer rise can be seen upon infection and reinfection (Wang and Grayston, 1986).

Despite of considerable efforts, persistent infections are difficult to diagnose, and no widely accepted serological criteria for persistent infection exist at present. IgG antibody can persist long after the acute phase (Puolakkainen et al., 1986; Paldanius et al., 2005), and only reflects (previous) exposure to the organisms. Some markers have yet been brought forward. Elevated IgE levels are almost always associated with asthma, a proposed manifestation of persistent $C$. pneumoniae infection, but the inducing factor for the IgE response has largely remained unknown. In a recent case-control study, C. pneumoniae-specific IgE antibody response was strongly associated with asthma and with severity of asthma in adults (Hahn et al., 2012). IgA antibodies are naturally short-lived with a half-life of 5-6 days. Consistently present/elevated C. pneumoniae IgA antibody titers (Saikku et al., 1992), and elevated serum C. pneumoniae IgA and IgG antibodies together with elevated C-reactive protein (Huittinen et al., 2003; Miya et al., 2004; Sävykoski et al., 2004) have been proposed as serological markers of persistent C. pneumoniae infection. IgA response could also be a predictor of treatment response (Hahn et al., 2006). Additionally, an association between C. pneumoniae IgA and human Hsp60 antibodies noted in patients with risk of coronary events (Huittinen et al., 2002) suggests that antibodies to human Hsp60 could be induced by bacterial GroEL (C. pneumoniae Hsp60 homolog, CPn0134) during persistent infection. Likewise, enhanced antibody response to C. trachomatis $\mathrm{EB}$ and chlamydial GroEL (C. trachomatis Hsp60 homolog, CT110) protein is associated with trachoma (Skwor et al., 2010) subfertility (Karinen et al., 2004), infertility, especially tubal factor infertility, a manifestation of persistent $C$. trachomatis infection (Toye et al., 1993; Witkin et al., 1998; Tiitinen et al., 2006).

Although the performance of the serological assays using whole bacteria as antigen and developed for the detection of acute infection might not be perfect, they have been valuable in epidemiological studies and when patient populations with a given condition have been studied. Moreover, the expanding clinical spectrum of chlamydial diseases, including those associated with persistent infection, was initially based on the findings obtained with the traditional but specific chlamydial serology. The antibodies recognized by the MIF are directed against the surface proteins of the chlamydial EB. OmpA (major outer membrane protein) is a dominant immunogen in C. trachomatis, but the (C. pneumoniae) proteins contributing to the MIF reactivity have largely remained 
unknown (Bunk et al., 2008). Proteomic analyses of chlamydial infection have revealed that a part of the surface proteins are more frequently and a part of them less frequently expressed during persistent than acute infection. Consequently, the MIF test as well as the EIAs using whole bacterial antigen might not be able to adequately discriminate between acute and persistent infections (Bunk et al., 2008). In support of this observation, reactivity of the sera from individuals with persistent infection in the MIF tests is necessarily not reflected by the reactivity of these sera with differentially expressed antigens, including chlamydial GroEL (Huhtinen et al., 2001; Bunk et al., 2008).

Proteomic profiling of chlamydial infection may enable the development of more precise serological assays that could better differentiate responses related to acute infection, cured past infection (serological scar) and persistent infection. The history and clinical status of the patients donating the serum specimens must be characterized appropriately. This is not always possible and straightforward, and may need invasive and extensive examinations. To identify antibody response patterns associated with persistent C. pneumoniae infection, Bunk et al. (2008) applied a proteomic approach with 2D-gel electrophoresis combined with immunoblotting. Using serum specimens from patients with probable persistent infection, based on the presence of C. pneumoniae DNA in their coronary arteries or in their PBMC, and blood donors without such markers of persistent infection, the researchers could identify a differential response against 12 C. pneumoniae antigens, including both increased and decreased reactivity (Bunk et al., 2008). Sera from the PCR-positive individuals reacted more intensely with C. pneumoniae CPn0695 (OmpA) and CPn0134 (GroEL) [and also with 6 other antigens, CPn0626 (RpoA), CPn0702 (YscC), CPn449/450 (Pmp10), CPn0854 (PorB), CPn0963 (Pmp21), and CPn1016 (Cpaf)] than sera from controls. The observed antibody response pattern was in accordance with the earlier mentioned in vitro proteomic studies showing higher and lower seroreactivity toward the proteins that were shown to be up-regulated and down-regulated, respectively, during IFN- $\gamma$-mediated persistence (Molestina et al., 2002; Mukhopadhyay et al., 2006). A recent description of a C. pneumoniae ORFeome library covering 99\% of the 1052 the ORFs of $C$. pneumoniae provides an additional novel tool for studying the seroresponses during persistent phase in-depth (Maier et al., 2012).

To identify novel C. trachomatis proteins or protein combinations associated with different stages of infection, a highresolution whole genome scale protein array (Wang et al., 2010) has been used to profile serological responses. Sera from patients with tubal factor infertility (TFI) and their controls recognized many C. trachomatis proteins (Wang et al., 2010). Comparison of the antibody profiles revealed that the sera from TFI patients preferentially recognized 30 C. trachomatis proteins. Those included CT110 (GroEL; 71\% of sera reacted with this protein) confirming the earlier findings that response to the Hsp60 homolog is associated with TFI. In this study, no single antigen yielded $100 \%$ specificity and $>50 \%$ sensitivity for detection of TFI, whereas a combination of CT443 (omcB) and CT381 (arginine binding protein) antigens yielded the highest detection sensitivity (68\%) for chlamydial TFI while maintaining
100\% specificity (Rodgers et al., 2011). However, also C. trachomatis antibody-positive individuals with acute C. trachomatis infection frequently reacted with GroEL, and diminished the value of this antigen as a marker of persistent infection. Subsequently, panels of $C$. trachomatis antigens that could predict tubal pathology and acute infection have been suggested. Using the same high-resolution approach, reactivity with four proteins [CT110 (GroEL), CT376 (malate dehydrogenase), CT557 (dihydrolipoamide hydrolase), and CT443 (OmcB)] could distinguish women with TFI from fertile women with a sensitivity of $63 \%$ and specificity of $100 \%$. Reactivity with a combination of two C. trachomatis antigens (CT875 and CT147, both coding for hypothetical proteins) could discriminate between women with acute infection and those with TFI (Budrys et al., 2012) enabling sequential screening to identify patients with these conditions.

\section{CONCLUSION}

A serum-based assay (either for antibody detection, antigen detection or nucleic acid amplification) would be desirable for the detection of persistent infection. Serum samples are relatively easily obtained whereas tissue samples from the site of persistent infection are not readily available. The above-mentioned recent studies utilizing proteomics and bacterial genome wide approaches by Bunk et al. (2008), Rodgers et al. (2011) and Budrys et al. (2012) indicate that chlamydial serology can be made more precise and refined. These studies also demonstrate the first evidence of differential serological response as a function of the infection status. Discrimination of antibody response related to persistent infection from that related to acute infection and from a serological scar is important and clinically relevant, and these promising approaches wait to be confirmed in studies with larger populations.

\section{ACKNOWLEDGMENTS}

Mirja Puolakkainen has received support from the Academy of Finland (grant\#110340), in the framework of the ERA-NET PathoGenoMics, \#217554/ECIBUG and\#130043/ChlamyTrans, as well as from the Helsinki-Uusimaa Hospital District (a research grant TYH2013405) and Helsinki University Central Hospital, Laboratory Division (HUSLAB) (research and development grant MLE82TK013).

\section{REFERENCES}

Barlow, R. E., Cooke, I. D., Odukoya, O., Heatley, M. K., Jenkins, J., Narayansingh, G., et al. (2001). The prevalence of Chlamydia trachomatis in fresh tissue specimens from patients with ectopic pregnancy or tubal factor infertility as determined by PCR and in-situ hybridisation. J. Med. Microbiol. 50, 902-908.

Beatty, W. L., Byrne, G. I., and Morrison, R. P. (1993). Morphologic and antigenic characterization of interferon gamma-mediated persistent Chlamydia trachomatis infection in vitro. Proc. Natl. Acad. Sci. U.S.A. 90, 3998-4002. doi: 10.1073/pnas.90.9.3998

Beatty, W. L., Morrison, R. P., and Byrne, G. I. (1994). Persistent Chlamydiae: from cell culture to paradigm for chlamydial pathogenesis. Microbiol. Rev. 58, 686-699.

Biasucci, L. M., Liuzzo, G., Ciervo, A., Petrucca, A., Piro, M., Angiolillo, D. J., et al. (2003). Antibody response to chlamydial heat shock protein 60 is 
strongly associated with acute coronary syndromes. Circulation 107, 3015-7. doi: 10.1161/01.CIR.0000078632.76653.6C

Bobryshev, Y. V., Killingsworth, M. C., Tran, D., and Lord, R. (2008). Amalgamation of Chlamydia pneumoniae inclusions with lipid droplets in foam cells in human atherosclerotic plaque. Virchows Arch. 453, 69-77. doi: 10.1007/s00428-0080629-2

Borel, N., Pospischil, A., Dowling, R. D., Dumrese, C., Gaydos, C. A., Bunk, S., et al. (2012). Antigens of persistent Chlamydia pneumoniae within coronary atheroma from patients undergoing heart transplantation. J. Clin. Pathol. 65 , 171-177. doi:10.1136/jclinpath-2011-200270

Brunham, R. C., Maclean, I. W., Binns, B., and Peeling, R. W. (1985). Chlamydia trachomatis: its role in tubal infertility. J. Infect. Dis. 152, 1275-1282. doi: 10.1093/infdis/152.6.1275

Budrys, N. M., Gong, S., Rodgers, A. K., Wang, J., Louden, C., Shain, R., et al. (2012). Chlamydia trachomatis antigens recognized in women with tubal factor infertility, normal fertility, and acute infection. Obstet. Gynecol. 119, 1009-1016. doi: 10.1097/AOG.0b013e3182519326

Bunk, S., Susnea, I., Rupp, J., Summersgill, J. T., Maass, M., Stegmann, W., et al. (2008). Immunoproteomic identification and serological responses to novel Chlamydia pneumoniae antigens that are associated with persistent $C$. pneumoniae infections. J. Immunol. 180, 5490-5498.

Burton, M. J., Holland, M. J., Jeffries, D., Mabey, D. C., and Bailey, R. L. (2006). Conjunctival chlamydial $16 \mathrm{~S}$ ribosomal RNA expression in trachoma: is chlamydial metabolic activity required for disease to develop? Clin. Infect. Dis. 42, 463-70. doi: 10.1086/499814

Campbell, L. A., and Kuo, C. C. (2004). Chlamydia pneumoniae-an infectious risk factor for atherosclerosis? Nat. Rev. Microbiol. 2, 23-32. doi: 10.1038/nrmicro796

Campbell, L. A., Patton, D. L., Moore, D. E., Cappuccio, A. L., Mueller, B. A., and Wang, S. P. (1993). Detection of Chlamydia trachomatis deoxyribonucleic acid in women with tubal infertility. Fertil. Steril. 59, 45-50.

Cappuccio, A. L., Patton, D. L., Kuo, C. C., and Campbell, L. A. (1994). Detection of Chlamydia trachomatis deoxyribonucleic acid in monkey models (Macaca nemestrina) of salpingitis by in situ hybridization: implications for pathogenesis. Am. J. Obstet. Gynecol. 171, 102-110. doi: 10.1016/S0002-9378(94)70085-0

Cotter, T. W., Miranpuri, G. S., Ramsey, K. H., Poulsen, C. E., and Byrne, G. I. (1997). Reactivation of chlamydial genital tract infection in mice. Infect. Immun. 65, 2067-2073.

Dean, D., Suchland, R. J., and Stamm, W. E. (2000). Evidence for long-term cervical persistence of Chlamydia trachomatis by omp1 genotyping. J. Infect. Dis. 182, 909-916. doi: 10.1086/315778

Emre, U., Sokolovskaya, N., Roblin, P. M., Schachter, J., and Hammerschlag, M. R. (1995). Detection of anti-Chlamydia pneumoniae IgE in children with reactive airway disease. J. Infect. Dis. 172, 265-267. doi: 10.1093/infdis/172.1.265

Falck, G., Gnarpe, J., and Gnarpe, H. (1996). Persistent Chlamydia pneumoniae infection in a Swedish family. Scand. J. Infect. Dis. 28, 271-3. doi: $10.3109 / 00365549609027171$

Gérard, H. C., Branigan, P. J., Schumacher, H. R. Jr., and Hudson, A. P. (1998). Synovial Chlamydia trachomatis in patients with reactive arthritis/Reiter's syndrome are viable but show aberrant gene expression. J. Rheumatol. 25, 734-742.

Gérard, H. C., Freise, J., Wang, Z., Roberts, G., Rudy, D., Krauss-Opatz, B., et al. (2002). Chlamydia trachomatis genes whose products are related to energy metabolism are expressed differentially in active vs. persistent infection. Microbes Infect. 4, 13-22. doi: 10.1016/S1286-4579(01)01504-0

Gérard, H. C., Whittum-Hudson, J. A., and Hudson, A. P. (1997). Genes required for assembly and function of the protein synthetic system in Chlamydia trachomatis are expressed early in elementary to reticulate body transformation. Mol. Gen. Genet. 255, 637-642. doi: 10.1007/s004380050538

Goellner, S., Schubert, E., Liebler-Tenorio, E., Hotzel, H., Saluz, H. P., and Sachse, K. (2006). Transcriptional response patterns of Chlamydophila psittaci in different in vitro models of persistent infection. Infect. Immun. 74, 4801-4808. doi: 10.1128/IAI.01487-05

Grayston, J. T. (1992). Infections caused by Chlamydia pneumoniae strain TWAR. Clin. Infect. Dis. 15, 757-761. doi: 10.1093/clind/15.5.757

Grayston, J. T., Kuo, C. C., Wang, S. P., and Altman, J. (1986). A new Chlamydia psittaci strain, TWAR isolated in acute respiratory tract infections. N. Engl. J. Med. 315, 161-168. doi: 10.1056/NEJM198607173150305

Grayston, J. T., and Wang, S. P. (1975). New knowledge of chlamydiae and disease they cause. J. Infect. Dis. 132, 87-104. doi: 10.1093/infdis/132.1.87
Hahn, D. L., Dodge, R. W., Golubjatnikov, R. (1991). Association of Chlamydia pneumoniae (strain TWAR) infection with wheezing, asthmatic bronchitis, and adult-onset asthma. JAMA 266, 225-30. doi: 10.1001/jama.1991.03470020051031

Hahn, D. L., Peeling, R. W., Dillon, E., McDonald, R., and Saikku, P. (2000). Serologic markers for Chlamydia pneumoniae in asthma. Ann. Allergy Asthma Immunol. 84, 227-33. doi: 10.1016/S1081-1206(10)62760-3

Hahn, D. L., Plane, M. B., Mahdi, O. S., and Byrne, G. I. (2006). Secondary outcomes of a pilot randomized trial of azithromycin treatment for asthma. PLoS Clin. Trials 1:e11. doi: 10.1371/journal.pctr.0010011

Hahn, D. L., Schure, A., Patel, K., Childs, T., Drizik, E., and Webley, W. (2012). Chlamydia pneumoniae-specific IgE is prevalent in asthma and is associated with disease severity. PLoS ONE 7:e35945. doi: 10.1371/journal.pone.0035945

Hahn, D., and Saikku, P. (1995). Serologic evidence for Chlamydia pneumoniae infection in recently symptomatic asthma: a pilot case-control study. Am. J. Respir. Crit. Care Med. 151(suppl. 2), A470.

Havlichek, D. H. Jr., Mauck, C., Mummaw, N. L., Moorer, G., Rajan, S. J., and Mushahwar, I. K. (1990). Comparison of chlamydial culture with Chlamydiazyme assay during erythromycin PCE treatment of Chlamydia genital infection. Sex. Transm. Dis. 17, 48-50.

Hogan, R. J., Mathews, S. A., Kutlin, A., Hammerschlag, M. R., and Timms, P. (2003). Differential expression of genes encoding membrane proteins between acute and continuous Chlamydia pneumoniae infections. Microb. Pathog. 34, 11-16. doi: 10.1016/S0882-4010(02)00187-0

Hogan, R. J., Mathews, S. A., Mukhopadhyay, S., Summersgill, J. T., and Timms, P. (2004). Chlamydial persistence: beyond the biphasic paradigm. Infect. Immun. 72, 1843-1855. doi: 10.1128/IAI.72.4.1843-1855.2004

Hudson, A. P., McEntee, C. M., Reacher, M., Whittum-Hudson, J. A., and Taylor, H. R. (1992). Inapparent ocular infection by Chlamydia trachomatis in experimental and human trachoma. Curr. Eye Res. 11, 279-283. doi: $10.3109 / 02713689209001780$

Huhtinen, M., Puolakkainen, M., Laasila, K., Sarvas, M., Karma, A., and LeirisaloRepo, M. (2001). Chlamydial antibodies in patients with previous acute anterior uveitis. Invest. Ophthalmol. Vis. Sci. 42, 1816-1819. doi: 10.1016/S00029394(01)01222-3

Huittinen, T., Hahn, D., Anttila, T., Wahlström, E., Saikku, P., and Leinonen M. (2001). Host immune response to Chlamydia pneumoniae heat shock protein 60 is associated with asthma. Eur. Respir. J. 17, 1078-1082. doi: $10.1183 / 09031936.01 .00089001$

Huittinen, T., Leinonen, M., Tenkanen, L., Mänttäri, M., Virkkunen, H., Pitkänen, T., et al. (2002). Autoimmunity to human heat shock protein 60 , Chlamydia pneumoniae infection, and inflammation in predicting coronary risk. Arterioscler. Thromb. Vasc. Biol. 22, 431-437. doi: 10.1161/hq0302.104512

Huittinen, T., Leinonen, M., Tenkanen, L., Virkkunen, H., Mänttäri, M., Palosuo, T., et al. (2003). Synergistic effect of persistent Chlamydia pneumoniae infection, autoimmunity, and inflammation on coronary risk. Circulation 107, 2566-2570. doi: 10.1161/01.CIR.0000068338.17948.22

Karinen, L., Pouta, A., Hartikainen, A. L., Bloigu, A., Paldanius, M., Leinonen, M., et al. (2004). Antibodies to Chlamydia trachomatis heat shock proteins Hsp60 and Hsp10 and subfertility in general population at age 31. Am. J. Reprod. Immunol. 52, 291-297. doi: 10.1111/j.1600-0897.2004.00223.x

Klos, A., Thalmann, J., Peters, J., Gérard, H. C., and Hudson, A. P. (2009). The transcript profile of persistent Chlamydophila (Chlamydia) pneumoniae in vitro depends on the means by which persistence is induced. FEMS Microbiol. Lett. 291, 120-126. doi: 10.1111/j.1574-6968.2008.01446.x

Kuo, C. C., and Campbell, L. A. (2000). Detection of Chlamydia pneumoniae in arterial tissues. J. Infect. Dis. 181(Suppl. 3), S432-S436. doi: 10.1086/315615

Kuo, C. C., Shor, A., Campbell, L. A., Fukushi, H., Patton, D. L., and Grayston, J. T. (1993). Demonstration of Chlamydia pneumoniae in atherosclerotic lesions of coronary arteries. J. Infect. Dis. 167, 841-849. doi: 10.1093/infdis/167.4.841

Kutlin, A., Roblin, P. M., and Hammerschlag, M. R. (1999). In vitro activities of azithromycin and ofloxacin against Chlamydia pneumoniae in a continuousinfection model. Antimicrob. Agents Chemother. 43, 2268-2272.

Laitinen, K., Laurila, A. L., Leinonen, M., and Saikku, P. (1996). Reactivation of Chlamydia pneumoniae infection in mice by cortisone treatment. Infect. Immun. $64,1488-1490$

Lee, C. K., and Moulder, J. W. (1981). Persistent infection of mouse fibroblasts (McCoy cells) with a trachoma strain of Chlamydia trachomatis. Infect. Immun. $32,822-829$. 
Leinonen, M., Linnanmäki, E., Mattila, K., Nieminen, M. S., Valtonen, V., LeirisaloRepo, M., et al. (1990). Circulating immune complexes containing chlamydial lipopolysaccharide in acute myocardial infarction. Microb. Pathog. 9, 67-73. doi: 10.1016/0882-4010(90)90042-O

Linhares, I. M., and Witkin, S. S. (2010). Immunopathogenic consequences of Chlamydia trachomatis $60 \mathrm{kDa}$ heat shock protein expression in the female reproductive tract. Cell Stress Chaperones 15, 467-473. doi: 10.1007/s12192-0100171-4

Linnanmäki, E., Leinonen, M., Mattila, K., Nieminen, M. S., Valtonen, V., and Saikku, P. (1993). Chlamydia pneumoniae-specific circulating immune complexes in patients with chronic coronary heart diseases. Circulation 87, 1130-1134. doi: 10.1161/01.CIR.87.4.1130

Mabey, D., and Solomon, A. W. (2003). Application of molecular tools in the control of blinding trachoma. Am. J. Trop. Med. Hyg. 69(Suppl. 5), 11-17.

Mahdi, O. S., Horne, B. D., Mullen, K., Muhlestein, J. B., and Byrne, G. I. (2002). Serum immunoglobulin $\mathrm{G}$ antibodies to chlamydial heat shock protein 60 but not to human and bacterial homologs are associated with coronary artery disease. Circulation 106, 1659-1663. doi: 10.1161/01.CIR.0000031567.10814.D8

Maier, C. J., Maier, R. H., Virok, D. P., Maass, M, Hintner, H, Bauer, J. W., et al. (2012). Construction of a highly flexible and comprehensive gene collection representing the ORFeome of the human pathogen Chlamydia pneumoniae. BMC Genomics 16:632. doi: 10.1186/1471-2164-13-632

Malinverni, R., Kuo, C. C., Campbell, L. A., and Grayston, J. T. (1995). Reactivation of Chlamydia pneumoniae lung infection in mice by cortisone. J. Infect. Dis. 172, 593-594. doi: 10.1093/infdis/172.2.593

Mannonen, L., Kamping, E., Penttilä, T., and Puolakkainen, M. (2004). IFNg induced persistent Chlamydia pneumoniae infection in HL and MonoMac 6 cells: characterization by real-time quantitative PCR and culture. Microb. Pathog. 36, 41-50. doi: 10.1016/j.micpath.2003.09.001

Mannonen, L., Markkula, E., and Puolakkainen, M. (2011). Analysis of Chlamydia pneumoniae infection in mononuclear cells by reverse transcription-PCR targeted to chlamydial gene transcripts. Med. Microbiol. Immunol. 200, 143-154. doi: 10.1007/s00430-011-0184-3

Mäurer, A. P., Mehlitz, A., Mollenkopf, H. J., and Meyer, T. F. (2007). Gene expression profiles of Chlamydophila pneumoniae during the developmental cycle and iron-depletion-mediated persistence. PLoS Pathog. 3:e83. doi: 10.1371/journal.ppat.0030083

Miya, N., Oguchi, S., Watanabe, I., and Kanmatsuse, K. (2004). Relation of secretory phospholipase $\mathrm{A}(2)$ and high-sensitivity C-reactive protein to Chlamydia pneumoniae infection in acute coronary syndromes. Circ. J. 68, 628-633. doi: 10.1253/circj.68.628

Miyashita, N., Fukano, H., Hara, H., Yoshida, K., Niki, Y., and Matsushima, T. (2002). Recurrent pneumoniae due to persistent Chlamydia pneumoniae infection. Intern. Med. 41, 30-33. doi: 10.2169/internalmedicine.41.30

Moazed, T. C., Kuo, C. C., Grayston, J. T., and Campbell, L. A. (1998). Evidence of systemic dissemination of Chlamydia pneumoniae via macrophages in the mouse. J. Infect. Dis. 177, 1322-1325. doi: 10.1086/515280

Molestina, R. E., Klein, J. B., Miller, R. D., Pierce, W. H., Ramirez, J. A., and Summersgill, J. T. (2002). Proteomic analysis of differentially expressed Chlamydia pneumoniae genes during persistent infection of HEp2-cells. Infect. Immun. 70, 2976-2981. doi: 10.1128/IAI.70.6.2976-2981.2002

Moulder, J. W., Levy, N. J., and Schulman, R. P. (1980). Persistent infection of mouse fibroblasts (L cells) with Chlamydia psittaci: evidence for a cryptic chlamydial form. Infect. Immun. 30, 874-883.

Mukhopadhyay, S., Miller, R. D., Sullivan, E. D., Theodoropoulos, C., Mathews, S. A., Timms, P., et al. (2006). Protein expression profiles of Chlamydia pneumoniae in models of persistence versus those of heat shock stress response. Infect. Immun. 74, 3853-3863. doi: 10.1128/IAI.02104-05

Nicholson, T. L., Olinger, L., Chong, K., Schoolnik, G., and Stephens, R. S. (2003). Global stage-specific gene regulation during the developmental cycle of Chlamydia trachomatis. J. Bacteriol. 185, 3179-3189. doi: 10.1128/JB.185.10.3179-3189.2003

Ouellette, S. P., Hatch, T. P., AbdelRahman, Y. M., Rose, L. A., Belland, R. J., and Byrne, G. I. (2006). Global transcriptional upregulation in the absence of increased translation in Chlamydia during IFNgamma-mediated host cell tryptophan starvation. Mol. Microbiol. 62, 1387-401. doi: 10.1111/j.13652958.2006.05465.x

Paldanius, M., Bloigu, A., Alho, M., Leinonen, M., and Saikku, P. (2005). Prevalence and persistence of Chlamydia pneumoniae antibodies in healthy laboratory personnel in Finland. Clin. Diagn. Lab. Immunol. 12, 654-659. doi: 10.1128/ CDLI.12.5.654-659.2005

Patton, D. L., Askienazy-Elbhar, M., Henry-Suchet, J., Campbell, L. A., Cappuccio, A., Tannous, W., et al. (1994). Detection of Chlamydia trachomatis in fallopian tube tissue in women with postinfectious tubal infertility. Am. J. Obstet. Gynecol. 171, 95-101. doi: 10.1016/S0002-9378(94) 70084-2

Peeling, R. W., Wang, S. P., Grayston, J. T., Blasi, F., Boman, J., Clad, A., et al. (2000). Chlamydia pneumoniae serology: interlaboratory variation in microimmunofluorescence assay results. J. Infect. Dis. 181(Suppl. 3), S426-S429. doi: $10.1086 / 315603$

Pesonen, E., El-Segaier, M., Persson, K., Puolakkainen, M., Sarna, S., Ohlin, H., et al. (2009a). Infections as a stimulus for coronary occlusion, obstruction, or acute coronary syndromes. Ther. Adv. Cardiovasc. Dis. 3, 447-454. doi: $10.1177 / 1753944709345598$

Pesonen, E., Tiirola, T., Andsberg, E., Jauhiainen, M., Paldanius, M., Persson, K., et al. (2009b). Serum chlamydial lipopolysaccharide as a prognostic factor for a new cardiovascular event. Heart Lung 38, 176-181. doi: 10.1016/j.hrtlng.2008.06.001

Phillips Campbell, R., Kintner, J., Whittimore, J., and Schoborg, R. V. (2012). Chlamydia muridarum enters a viable but non-infectious state in amoxicillin-treated BALB/c mice. Microbes Infect 14:1177-1185. doi: 10.1016/j.micinf.2012.07.017

Puolakkainen, M., Vesterinen, E., Purola, E., Saikku, P., and Paavonen, J. (1986). Persistence of chlamydial antibodies after pelvic inflammatory disease. J. Clin. Microbiol. 23, 924-928.

Rodgers, A. K., Budrys, N. M., Gong, S., Wang, J., Holden, A., Schenken, R. S., et al. (2011). Genome-Wide Identification of Chlamydia trachomatis Antigens Associated with Tubal Factor Infertility. Fertil. Steril. 96, 715-721. doi: 10.1016/j.fertnstert.2011.06.021

Rosenfeld, M. E., and Campbell, L. A. (2011). Pathogens and atherosclerosis: update on the potential contribution of multiple infectious organisms to the pathogenesis of atherosclerosis. Thromb. Haemost. 106, 858-867. doi: 10.1160/TH11-06-0392

Saikku, P., Leinonen, M., Tenkanen, L., Linnanmäki, E., Ekman, M. R., Manninen, V., et al. (1992). Chronic Chlamydia pneumoniae infection as a risk factor for coronary heart disease in the Helsinki Heart Study. Ann. Intern. Med. 116, 273-278. doi: 10.7326/0003-4819-116-4-273

Sarov, I., Kleinman, D., Holcberg, G., Potashnik, G., Insler, V., Cevenini, R., et al. (1986). Specific IgG and IgA antibodies to Chlamydia trachomatis in infertile women. Int. J. Fertil. 31, 193-197.

Sävykoski, T., Harju, T., Paldanius, M., Kuitunen, H., Bloigu, A., Wahlström, E., et al. (2004). Chlamydia pneumoniae infection and inflammation in adults with asthma. Respiration 71, 120-125. doi: 10.1159/000076671

Skwor, T., Kandel, R. P., Basravi, S., Khan, A., Sharma, B., and Dean, D. (2010). Characterization of humoral immune responses to chlamydial HSP60, C. P.AF, and CT795 in inflammatory and severe trachoma. Invest. Ophthalmol. Vis. Sci. 51, 5128-5136. doi: 10.1167/iovs.09-5113

Spagnoli, L. G., Pucci, S., Bonanno, E., Cassone, A., Sesti, F., Ciervo, A., et al. (2007). Persistent Chlamydia pneumoniae infection of cardiomyocytes is correlated with fatal myocardial infarction. Am. J. Pathol. 170, 33-42. doi: 10.2353/ajpath.2007.051353

Tarnacka, B., Gromadzka, G., and Członkowska, A. (2002). Increased circulating immune complexes in acute stroke: the triggering role of Chlamydia pneumoniae and cytomegalovirus. Stroke 33, 936-940. doi: 10.1161/01.STR.0000014562.75483.6B

Tiirola, T., Jaakkola, A., Bloigu, A., Paldanius, M., Sinisalo, J., Nieminen, M. S., et al. (2006). Novel enzyme immunoassay utilizing lipopolysaccharidebinding protein as a capture molecule for the measurement of chlamydial lipopolysaccharide in serum. Diagn. Microbiol. Infect. Dis. 54, 7-12. doi: 10.1016/j.diagmicrobio.2005.09.001

Tiirola, T., Sinisalo, J., Nieminen, M. S., Silvennoinen-Kassinen, S., Paldanius, M., Saikku, P., et al. (2007). Chlamydial lipopolysaccharide is present in serum during acute coronary syndrome and correlates with CRP levels. Atherosclerosis 194, 403-407. doi: 10.1016/j.atherosclerosis.2006.08.013

Tiitinen, A., Surcel, H. M., Halttunen, M., Birkelund, S., Bloigu, A., Christiansen, G., et al. (2006). Chlamydia trachomatis and chlamydial heat shock protein 60 specific antibody and cell-mediated responses predict tubal factor infertility. Hum. Reprod. 21, 1533-1538. doi: 10.1093/humrep/del014 
Toye, B., Laferrière, C., Claman, P., Jessamine, P., and Peeling, R. (1993). Association between antibody to the chlamydial heat-shock protein and tubal infertility. J. Infect. Dis. 168, 1236-1240. doi: 10.1093/infdis/168. 5.1236

Vikatmaa, P., Lajunen, T., Ikonen, T. S., Pussinen, P. J., Lepäntalo, M., Leinonen, M., et al. (2010). Chlamydial lipopolysaccharide (cLPS) is present in atherosclerotic and aneurysmal arterial wall-cLPS levels depend on disease manifestation. Cardiovasc. Pathol. 19, 48-54. doi: 10.1016/j.carpath.2008. 10.012

Volanen, I., Järvisalo, M. J., Vainionpää, R., Arffman, M., Kallio, K., et al. (2006). Increased aortic intima-media thickness in 11-year-old healthy children with persistent Chlamydia pneumoniae seropositivity. Arterioscler. Thromb. Vasc. Biol. 26, 649-655. doi: 10.1161/01.ATV.0000202664.76816.bb

Von Hertzen, L., Alakärppä, H., Koskinen, R., Liippo, K., Surcel, H. M., Leinonen, M., et al. (1997). Chlamydia pneumoniae infection in patients with chronic obstructive pulmonary disease. Epidemiol. Infect. 118, 155-164. doi: $10.1017 /$ S095026889600725X

von Hertzen, L., Surcel, H. M., Kaprio, J., Koskenvuo, M., Bloigu, A., Leinonen, M., et al. (1998). Immune responses to Chlamydia pneumoniae in twins in relation to gender and smoking. J. Med. Microbiol. 47, 441-446. doi: 10.1099/0022261547-5-441

Wang, J., Zhang, Y., Lu, C., Lei, L., Yu, P., and Zhong, G. (2010). A genome-wide profiling of the humoral immune response to Chlamydia trachomatis infection reveals vaccine candidate antigens expressed in humans. J. Immunol. 185, 1670-180. doi: 10.4049/jimmunol.1001240

Wang, S. P., and Grayston, J. T. (1986). "Microimmunofluorescence serological studies with the TWAR organism," in Chlamydial Infections. Proceedings of the Sixth International Symposium on Human Chlamydial Infections, eds D. Oriel, G. Ridgway, J. Schachter, D. Taylor-Robinson, and M. Ward (Cambridge), 329-332.
Wehrl, W., Meyer, T. F., Jungblut, P. R., Müller, E. C., and Szczepek, A. J. (2004). Action and reaction: Chlamydophila pneumoniae proteome alteration in a persistent infection induced by iron deficiency. Proteomics 4, 2969-2981. doi: 10.1002/pmic.200400917

Witkin, S. S., Askienazy-Elbhar, M., Henry-Suchet, J., Belaisch-Allart, J., TortGrumbach, J., and Sarjdine, K. (1998). Circulating antibodies to a conserved epitope of the Chlamydia trachomatis $60 \mathrm{kDa}$ heat shock protein (hsp60) in infertile couples and its relationship to antibodies to C. trachomatis surface antigens and the Escherichia coli and human HSP60. Hum. Reprod. 13, 1175-1179. doi: 10.1093/humrep/13.5.1175

Yang, Y. S., Kuo, C. C., and Chen, W. J. (1983). Reactivation of Chlamydia trachomatis lung infection in mice by cortisone. Infect. Immun. 39, 655-658.

Conflict of Interest Statement: The author declares that the research was conducted in the absence of any commercial or financial relationships that could be construed as a potential conflict of interest.

Received: 29 October 2013; accepted: 28 November 2013; published online: 17 December 2013.

Citation: Puolakkainen M (2013) Laboratory diagnosis of persistent human chlamydial infection. Front. Cell. Infect. Microbiol. 3:99. doi: 10.3389/fcimb.2013.00099

This article was submitted to the journal Frontiers in Cellular and Infection Microbiology.

Copyright (c) 2013 Puolakkainen. This is an open-access article distributed under the terms of the Creative Commons Attribution License (CC BY). The use, distribution or reproduction in other forums is permitted, provided the original author(s) or licensor are credited and that the original publication in this journal is cited, in accordance with accepted academic practice. No use, distribution or reproduction is permitted which does not comply with these terms. 